\title{
Diagnostic value and clinical laboratory associations of antibodies against recombinant ribosomal P0, P1 and P2 proteins and their native heterocomplex in a Caucasian cohort with systemic lupus erythematosus
}

Fidan Barkhudarova', Cornelia Dähnrich², Anke Rosemann², Udo Schneider', Winfried Stöcker², Gerd-Rüdiger Burmester ${ }^{1}$, Karl Egerer ${ }^{1}$, Wolfgang Schlumberger ${ }^{2}$, Falk Hiepe ${ }^{1 *}$, Robert Biesen ${ }^{1}$

\begin{abstract}
Introduction: In this study, we sought to determine the diagnostic value and clinical laboratory associations of autoantibodies against recombinant ribosomal P0, P1 and P2 proteins and their native heterocomplex in systemic lupus erythematosus (SLE).

Methods: Autoantibodies against recombinant ribosomal $\mathrm{P}$ proteins $\left(\mathrm{aRibP}_{\mathrm{R}} \mathrm{O}, \mathrm{aRibP}_{\mathrm{R}} 1\right.$ and $\left.a \mathrm{aRibP}_{\mathrm{R}} 2\right)$ and antibodies against native ribosomal $P$ heterocomplex $\left(a_{\mathrm{RibP}} \mathrm{H}\right)$ were determined in sera from patients with SLE $(n=163)$, systemic sclerosis $(n=66)$, Sjögren's syndrome $(n=54)$, rheumatoid arthritis $(n=90)$ and healthy donors $(n=100)$ using enzyme-linked immunosorbent assay. Test results were correlated to medical records, including the American College of Rheumatology criteria, the Systemic Lupus Erythematosus Disease Activity Index 2000, laboratory data and medications of all SLE patients.

Results: Sensitivities of $22.0 \%$ for aRibP $\mathrm{R}_{\mathrm{R}} \mathrm{O}, 14.9 \%$ for $\mathrm{aRibP}_{\mathrm{R}} 2,14.3 \%$ for aRibP $\mathrm{N}$ and $10.7 \%$ for $\mathrm{aRibP}_{\mathrm{R}} 1$ were obtained at a specificity of $99 \%$. The assay for $\mathrm{aRibP}_{\mathrm{R}} \mathrm{O}$ detection demonstrated the best performance in receiveroperating characteristics analysis, with $\mathrm{aRibP}_{\mathrm{R}} 0$ detectable in $10 \%$ of anti-Smith antibody and anti-double-stranded DNA-negative sera at a specificity of $100 \%$. ARibP $P_{R}$ positivity was associated with lymphocytopenia. $\mathrm{ARibP}_{\mathrm{R}} 1^{+}$ patients had significantly higher $\gamma$-glutamyl transpeptidase (GGT) levels than their aRibP $1^{-}$counterparts. No specific damage occurred in aRibP ${ }^{+}$lupus patients compared with a group of age-, sex- and nephritis-matched aRibPlupus patients within 3 years.

Conclusions: The determination of antibodies against ribosomal P proteins improves the diagnosis of SLE and should therefore be implemented in upcoming criteria for the diagnosis or classification of SLE. High titers of $\mathrm{aRibP}_{\mathrm{R}} \mathrm{O}$ can be associated with lymphocytopenia, and high titers of aRibP 1 can be associated with elevated GGT levels. So far, there is no evidence for a prognostic value of aRibPs for damage.
\end{abstract}

\footnotetext{
* Correspondence: falk.hiepe@charite.de

'Department of Rheumatology and Clinical Immunology, Charité

Universitätsmedizin Berlin, Chariteplatz 1, Berlin D-10117, Germany

Full list of author information is available at the end of the article
} 


\section{Introduction}

Systemic lupus erythematosus (SLE) is a chronic, multifaceted rheumatic disease which is characterised by the generation of autoantibodies predominantly directed against nuclear proteins and nucleic acids [1,2]. However, antibodies against cytoplasmatic antigens such as those binding to ribosomal $\mathrm{P}$ proteins (aRibPs) have been reported to be specific for SLE as well [2,3]. In contrast to anti-Smith (anti-Sm) and anti-double-stranded DNA (anti-dsDNA) antibodies, anti-ribosomal $\mathrm{P}$ protein antibodies are not included in the current American College of Rheumatology (ACR) classification criteria for SLE [4,5].

The human ribosomal phosphoproteins P0 (38 kDa), P1 $(19 \mathrm{kDa})$ and P2 $(17 \mathrm{kDa})$ are located within the $60 \mathrm{~S}$ ribosomal subunit, forming a pentameric complex consisting of a P0 anchor and two P1/P2 heterodimers [3]. The subunits of that pentamer have a common immunodominant epitope at the carboxyl terminus [6], which can lead to cross-reactions of anti-ribosomal P antibodies with P0, P1 and $\mathrm{P} 2$ units. $\mathrm{P}$ proteins can also exist as ribosome-free P0, P1 and P2 forms in the cytoplasm [6,7]. Notably, the P0-like protein is also detectable in the plasma membranes of hepatocytes, lymphocytes and other cells [8-11].

The prevalence of anti-ribosomal antibodies depends on the disease activity, the patient's ethnicity and the antigens used in detection systems [12-14]. There are reports about clinical associations of anti-ribosomal protein antibodies with short disease duration [15], rash $[16,17]$, lymphocytopenia [18] and lupus hepatitis [11,19-23]. Ohira et al. [22] showed that patients with lupus hepatitis have significantly higher and more frequent levels of antibodies against recombinant ribosomal P0 protein $\left(\mathrm{aRibP}_{\mathrm{R}} 0\right)$ than patients with autoimmune hepatitis. There are also contradictory reports of patients with juvenile onset SLE [24-27], neuropsychiatric SLE $[3,28,29]$, lupus nephritis class V $[3,27,30]$, high disease activity $[15,16,26,31]$ and low levels of complement component $3(\mathrm{C} 3)$ or complement component $4(\mathrm{C} 4)$ $[16,17,22,32]$.

A comparative investigation of the clinical laboratory associations of antibodies against recombinant ribosomal P0, P1 and P2 proteins $\left(a \operatorname{aRibP}_{\mathrm{R}} 0\right.$, $\mathrm{aRibP}_{\mathrm{R}} 1$ and $\left.\mathrm{aRibP}_{\mathrm{R}} 2\right)$ has never been conducted. Thus, the purpose of the present work was to determine the diagnostic value of antibodies against native ribosomal $\mathrm{P}$ heterocomplex $\left(\mathrm{aRibP}_{\mathrm{N}} \mathrm{H}\right)$, $\operatorname{aRibP}_{\mathrm{R}} 0, \mathrm{aRibP}_{\mathrm{R}} 1$ and $\mathrm{aRibP} \mathrm{R}_{\mathrm{R}} 2$ for SLE and to analyse their associations with disease features and future damage.

\section{Materials and methods \\ Study participants}

Altogether 479 serum samples were obtained from the following groups: (1) patients with SLE $(n=163)$, who fulfilled the American College of Rheumatology (ACR) 1982 revised criteria for the classification of SLE [4], (2) patients with systemic sclerosis (SSc, $n=66$ ) who met the ACR 1980 criteria for scleroderma [33], (3) patients with primary Sjögren's syndrome (pSS, $n=54$ ) who fulfilled the preliminary European League Against Rheumatism criteria of Vitali et al. [34], (4) patients with rheumatoid arthritis (RA, $n=90$ ) who met the ACR 1987 revised criteria for the classification of rheumatoid arthritis [35] and (5) healthy donors (HD, $n=100$ ).

Disease activity of SLE patients was defined based on the Systemic Lupus Erythematosus Disease Activity Index 2000 (SLEDAI 2000) [36-38] in 101 patients: 6 of them had no activity (SLEDAI score 0 ), 35 were mildly active $(0<$ SLEDAI $\leq 5), 41$ had moderate disease activity $(5<$ SLEDAI $\leq 10)$, 14 were highly active $(10<$ SLEDAI $\leq 20)$, and 5 had very high activity (SLEDAI $>20$ ). Juvenile onset was diagnosed when the age at diagnosis was 18 years or younger according to the Pediatric Rheumatology International Trials Organization [39]. Twenty-four (14.7\%) patients with juvenile onset SLE and 139 (85.3\%) patients with adult onset SLE were studied. Disease damage was measured according to the criteria of the Systemic Lupus International Collaborative Clinics (SLICC) $[40,41]$ and the weighted damage score (WDS) [40]. All patients were recruited from the outpatient and inpatient facilities of the Department of Rheumatology and Clinical Immunology, Charité University Hospital, Berlin, Germany. The Ethics Committee of the Medical Faculty of Charité University Hospital approved the study, and written informed consent was obtained from all subjects. Sera from healthy donors were used in cooperation with University of Lübeck, Germany. Written informed consent was obtained from all healthy subjects.

\section{Measurement of antibodies}

Microtiter plates (Nunc, Roskilde, Denmark) were coated with $1 \mu \mathrm{g} / \mathrm{ml}$ full-length recombinant ribosomal protein P0, P1 or P2 expressed in insect cells (DIARECT, Freiburg, Germany). Sera diluted 1:201 in phosphate-buffered saline (PBS) and $0.1 \%(\mathrm{wt} / \mathrm{vol})$ casein were added and allowed to react for 30 minutes, followed by three washing cycles with PBS $0.05 \%$ (vol/vol) and Tween 20. For detection of bound antibodies, the plates were incubated with antihuman immunoglobulin (IgG) peroxidase conjugate (EUROIMMUN, Lübeck, Germany) for 30 minutes, washed three times and allowed to react with tetramethylbenzidine (EUROIMMUN) for 15 minutes. After addition of acidic stopping solution (EUROIMMUN), the optical density (OD) was read at $450 \mathrm{~nm}$ using an automated spectrophotometer (Spectra Mini; Tecan, Crailsheim, Germany). All steps were performed at room temperature. A highly positive index patient serum was used to generate a standard curve consisting of three calibrators $(2,20$ and 200 
relative units $(\mathrm{RU}) / \mathrm{ml})$. Relative units per milliliter were calculated for all samples using this three-point standard curve. The analytical reproducibility of all aRibP assays was evaluated by repeated testing of two serum samples (10 determinations each) in the same run, giving intraassay coefficients of variation $(\mathrm{CV})$ of $2.4 \%\left(\mathrm{aRibP}_{\mathrm{R}} 0\right), 2.1 \%$ $\left(\mathrm{aRibP}_{\mathrm{R}} 1\right)$ and $2.7 \%\left(\mathrm{aRibP}_{\mathrm{R}} 2\right)$, respectively. Relationships between sensitivity and specificity at different cutoff values were examined for all assays by receiveroperating characteristics (ROC) curve analyses, allowing also for the determination of test characteristics at predefined specificities.

The anti-RibP ${ }_{\mathrm{N}} \mathrm{H}$ enzyme-linked immunosorbent assay (ELISA) (IgG, CV 2.6\%), anti-Sm ELISA, anti-dsDNA radioimmunoassay (RIA) (Farr assay) and anti-dsDNA ELISA are commercially available assays from EUROIMMIUN and were performed following the manufacturer's instructions.

\section{Statistical analysis}

Statistical analyses were performed using GraphPad Prism 5 software (GraphPad Software, La Jolla, CA, USA). The diagnostic significance of antiribosomal proteins N, P0, P1 and P2 antibodies was assessed and areas under the curve
(AUCs) were created using ROC analysis. To determine associations, the Mann-Whitney $U$ test (for comparing medians between groups; MWT), Fisher's exact test (FET) and Spearman's rank test (SRT) were used. Two-tailed $t$-tests were used throughout with an $\alpha$ set at 0.05 .

\section{Results}

Reactivity and diagnostic significance of antiribosomal proteins $\mathrm{N}, \mathrm{P} 0, \mathrm{P} 1$ and $\mathrm{P} 2$ antibodies

Antibodies against ribosomal $\mathrm{P}_{\mathrm{N}} \mathrm{H}, \mathrm{P}_{\mathrm{R}} \mathrm{O}, \mathrm{P}_{\mathrm{R}} 1$ and $\mathrm{P}_{\mathrm{R}} 2$ proteins (Figure 1), Sm and dsDNA (ELISA and Farr assays) were measured in sera from 163 SLE patients, 210 disease controls and 100 healthy donors to define and compare the sensitivity and specificity in ROC curve analysis (Table 1 ). For aRibP ${ }_{\mathrm{N}} \mathrm{H}$, a sensitivity of $5.5 \%$ and a specificity of $100 \%$ were calculated using the manufacturer's cutoff (20 $\mathrm{RU} / \mathrm{ml}$ ). At a predefined specificity of $98 \%$ among 210 patients with other rheumatic diseases (SSc, pSS and RA), only five $(2.4 \%)$, four $(1.9 \%)$, four $(1.9 \%)$ and four $(1.9 \%)$ had elevated $a \operatorname{RibP}_{\mathrm{N}} \mathrm{H}, \mathrm{aRibP}_{\mathrm{R}} 0$, aRibP 1 and $a \operatorname{RibP}_{\mathrm{R}} 2$ titers, respectively. At the same specificity among 100 healthy donors, only zero $(0 \%)$, one $(1.0 \%)$, two $(2.0 \%)$ and two (2.0\%) patients had high titers of aRibP $\mathrm{N}_{\mathrm{N}} \mathrm{H}$, aRibP $\mathrm{R}_{\mathrm{R}} 0$,
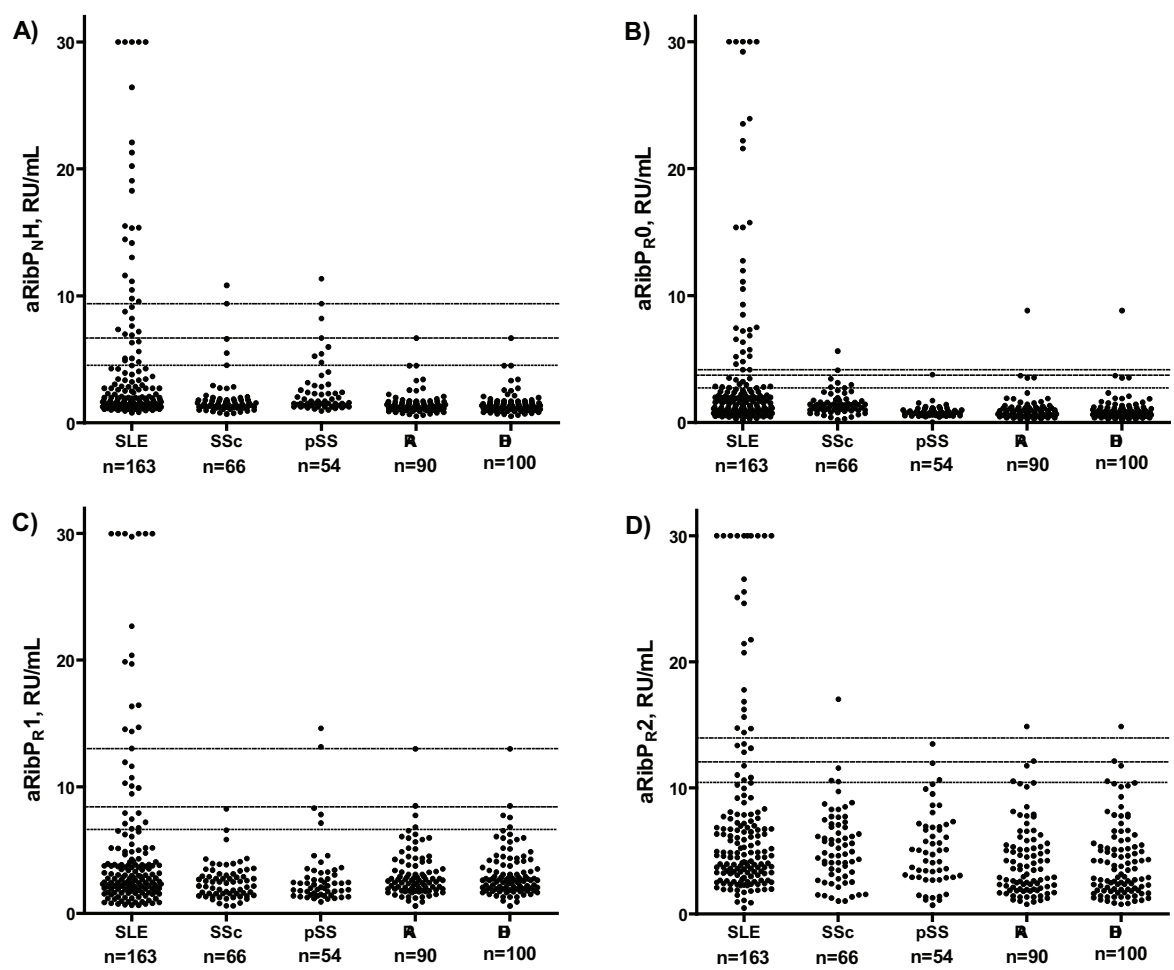

Figure 1 Graphs showing levels of antiribosomal P protein antibodies in SLE, other rheumatic diseases and healthy donors. Autoantibodies directed against (a) native ribosomal P heterocomplex (aRibP $\left.\mathrm{N}_{\mathrm{H}} \mathrm{H}\right)$, (b) recombinant ribosomal PO protein (aRibP $\left.\mathrm{R}_{\mathrm{R}} \mathrm{O}\right)$, (c) recombinant ribosomal P1 (aRibP 1 ) and (d) recombinant ribosomal P2 protein (aRibP ${ }_{R} 2$ ) were measured using enzyme-linked immunosorbent assay. Dotted lines represent the distinct cut-offs based on ROC curve analysis at specificities of 95\% (dotted line), 98\% (broken line) and 99\% (dotted and broken line). Values $>30 \mathrm{RU} / \mathrm{ml}$ were set to $30 \mathrm{RU} / \mathrm{ml}$ for clearer arrangement of the figures. SLE, systemic lupus erythematosus; SSc, systemic sclerosis; pSS, primary Sjögren's syndrome; RA, rheumatoid arthritis; HD, healthy donors. RU, relative units. 
Table 1 Test values of antiribosomal $P_{N} H, P_{R} 0, P_{R} 1$ and $P_{R} 2$ antibodies calculated in receiver-operating characteristics analysis $^{\mathrm{a}}$

\begin{tabular}{|c|c|c|c|c|c|c|c|}
\hline Statistics & $\operatorname{aRibP}_{N} \mathrm{H}$ & $\mathrm{aRibP}_{\mathrm{R}} 0$ & $\operatorname{aRibP}_{\mathrm{R}} 1$ & $\mathrm{aRibP}_{\mathrm{R}} 2$ & Anti-Sm & $\begin{array}{l}\text { Anti-dsDNA Farr } \\
\text { assay }\end{array}$ & $\begin{array}{l}\text { Anti-dsDNA } \\
\text { ELISA }\end{array}$ \\
\hline Area under curve & 0.7014 & $0.7368^{b}$ & 0.5811 & 0.6220 & 0.6791 & 0.8463 & 0.8621 \\
\hline $95 \% \mathrm{Cl}$ & $\begin{array}{l}0.65 \text { to } \\
0.75\end{array}$ & 0.69 to 0.79 & $\begin{array}{c}0.52 \text { to } \\
0.64\end{array}$ & 0.57 to 0.67 & $\begin{array}{c}0.62 \text { to } \\
0.74\end{array}$ & 0.80 to 0.89 & 0.82 to 0.90 \\
\hline$P$ value & $<0.0001$ & $<0.0001$ & 0.0021 & $<0.0001$ & $<0.0001$ & $<0.0001$ & $<0.0001$ \\
\hline Sensitivity at $95 \%$ specificity cutoff & $24.4 \%(4.5)$ & $29.2 \%(2.7)^{b}$ & $20.4 \%(6.6)$ & $20.2 \%(10.5)$ & $38.7 \%(2.0)$ & $61.4 \%(5.4)$ & $53.9 \%(73.9)$ \\
\hline Sensitivity at $98 \%$ specificity cutoff & $19.1 \%(6.7)$ & $22.0 \%(3.7)^{b}$ & $16.1 \%(8.4)$ & $17.9 \%(12.1)$ & $33.7 \%(2.4)$ & $56.4 \%(6.5)$ & $42.9 \%(105.8)$ \\
\hline Sensitivity at $99 \%$ specificity cutoff & $14.3 \%(9.4)$ & $22.0 \%(4.2)^{b}$ & $\begin{array}{l}10.7 \% \\
(13.0)\end{array}$ & $14.9 \%(13.9)$ & $19.6 \%(4.8)$ & $55.8 \%(6.8)$ & $37.4 \%(151.0)$ \\
\hline Sensitivity at $100 \%$ specificity cutoff & $11.9 \underset{b}{(11.5)}$ & $11.3 \%(9.1)$ & $8.9 \%(14.7)$ & $11.3 \%(17.4)$ & $12.3 \%(7.9)$ & $49.1 \%(9.0)$ & $31.3 \%(169.0)$ \\
\hline $\begin{array}{l}\text { Maximum sum of specificity and } \\
\text { sensivity }\end{array}$ & $133.2 \%$ & $140.7 \%^{\mathrm{b}}$ & $118.2 \%$ & $117.9 \%$ & $138.9 \%$ & $161.8 \%$ & $160.8 \%$ \\
\hline
\end{tabular}

${ }^{a} a_{i b P} \mathrm{~N}_{\mathrm{N}}$, antibody against native ribosomal $\mathrm{P}$ heterocomplex; aRibP $\mathrm{R}_{\mathrm{O}}$, antibody against recombinant ribosomal $\mathrm{PO}$ protein; aRibP $\mathrm{R}_{\mathrm{R}} 1$, antibody against recombinant ribosomal P1 protein; aRibP $_{\mathrm{R}}$ 2, antibody against recombinant ribosomal P2 protein; anti-Sm, anti-Smith antibody; anti-dsDNA, anti-double-stranded DNA antibody; ELISA, enzyme-linked immunosorbent assay; $95 \% \mathrm{Cl}, 95 \%$ confidence interval; ${ }^{b}$ highest values of sensitivity, area under the curve and lowest cutoff values (in parentheses) among autoantibodies against ribosomal $\mathrm{P}$ protein (aRibP).

${ }_{\text {aRibP }} 1$ and $\operatorname{aRibP}_{\mathrm{R}} 2$. Among antiribosomal $\mathrm{P}$ protein antibodies, $\mathrm{aRibP}_{\mathrm{R}} 0$ had the highest performance with regard to criteria such as AUC and maximum sum of sensitivity and specificity, followed by aRibP ${ }_{\mathrm{N}} \mathrm{H}$ (Table 1). All test criteria of $\mathrm{aRibP}_{\mathrm{R}} 0$ were inferior to those of the antidsDNA ELISA or the Farr assay, but were almost equal to those of the anti-Sm ELISA.

Patients negative for aRibP $\mathrm{N}_{\mathrm{H}}$ but positive for aRibP $\mathrm{R}_{\mathrm{P}} \mathrm{P}-2$ Although the native heterocomplex of ribosomal $\mathrm{P}$ contains all immunological domains of the subunits P0, P1 and P2, there were considerable differences in the cutoffs and in sensitivities for the detection of aRibP ${ }_{\mathrm{N}} \mathrm{H}$, $\operatorname{aRibP}_{\mathrm{R}} 0$, $\mathrm{aRibP}_{\mathrm{R}} 1$ and $\mathrm{aRibP}_{\mathrm{R}} 2$ (Table 1), with outstanding results for $a \operatorname{RibP}_{\mathrm{R}} 0$.

Thus, we further investigated whether there were patients negative for aRibP ${ }_{N} \mathrm{H}$ but positive for aRibP $\mathrm{R}_{\mathrm{R}} 0$, $a_{R i b P} 1$ or $a_{R i b P} 2$ (Figure 2). Sera fulfilling these criteria would point out that there are some epitopes of ribosomal P proteins that are not accessible to autoantibodies because of the spatial conformation of the native heterocomplex.
A)

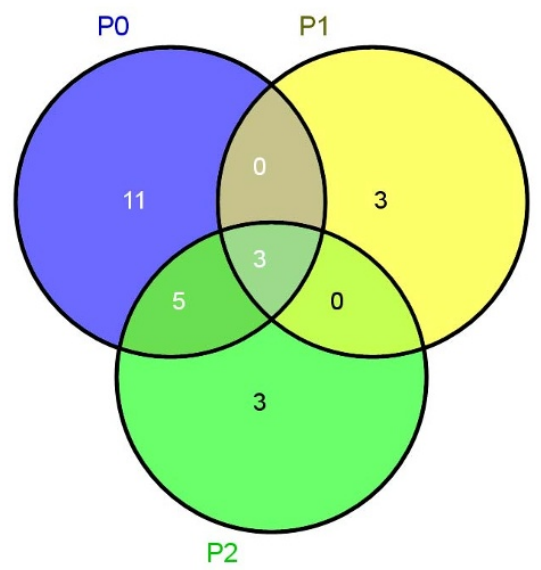

B)

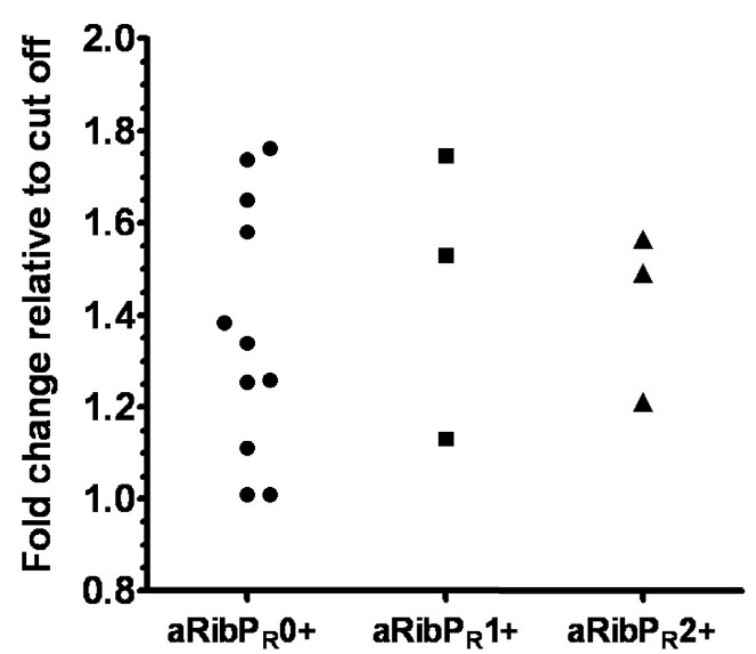

Figure 2 Frequencies of $\mathrm{aRibP}_{\mathrm{R}} \mathbf{0}$, $\mathrm{aRibP}_{\mathrm{R}} \mathbf{1}$ and $\mathrm{aRibP}_{\mathrm{R}} \mathbf{2}$ in aRibP $\mathrm{P}_{\mathrm{N}} \mathrm{H}$-negative lupus patients. (a) Results according to specificity of $99 \%$ are

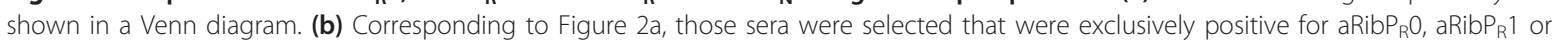
$\mathrm{aRibP}_{\mathrm{R}} 2$ among $\mathrm{aRibP}_{\mathrm{N}} \mathrm{H}$-negative SLE patients. To further show exact and comparable signal intensities, fold change indices in relation to the given cutoffs of each recombinant aRibP protein (see also Table 1) were calculated. ARibP $\mathrm{N}_{\mathrm{H}}$, antibodies against native ribosomal $\mathrm{P}$ heterocomplex; $\operatorname{aRibP}_{\mathrm{R}} \mathrm{O}$, antibodies against recombinant ribosomal P0 protein; $\mathrm{ARibP}_{\mathrm{R}}$ 1, antibodies against recombinant ribosomal $\mathrm{P} 1$ protein; $\operatorname{aRibP}_{R} 2$, antibodies against recombinant ribosomal P2 protein; aRibPs, anti-ribosomal P protein antibodies. 
At 99\% specificity, among $141 \mathrm{aRibP}_{\mathrm{N}} \mathrm{H}^{-}$patients there were $19(13.5 \%)$ positive for aRibP $\mathrm{R}_{\mathrm{R}} 0$, six (4.3\%) positive for aRibP $P_{R} 1$ and $11(7.8 \%)$ positive for $a_{R i b P} 2$. Some of those sera were further exclusively positive for one of the recombinant aRibPs and showed an increased titer up to twofold of the corresponding cutoff (Figure 2b).

Diagnostic value of anti-ribosomal $\mathrm{P}$ protein antibodies in SLE

To investigate the auxiliary diagnostic value of antiribosomal $\mathrm{P}$ protein antibodies in SLE, we searched for patients who were negative for antibodies against dsDNA and $\mathrm{Sm}$, but positive for $\operatorname{aRibP}_{\mathrm{N}} \mathrm{H}, \operatorname{aRibP}_{\mathrm{R}} 0$, aRibP $_{\mathrm{R}} 1$ or $\mathrm{aRibP}_{\mathrm{R}} 2$ at a specificity of $100 \%$ (Figure 3 ). This analysis was performed twice, taking either the results of the anti-dsDNA ELISA (Figure 3a) or those of the Farr assay (Figure $3 \mathrm{~b}$ ).

Among 163 SLE patients, there were 11 (6.7\%) individuals who could be diagnosed only by detection of aRibPs, while 63 (38.7\%) patients were regularly diagnosed by the presence of anti-dsDNA or anti-Sm antibodies. Considering the excellent Farr assay, these

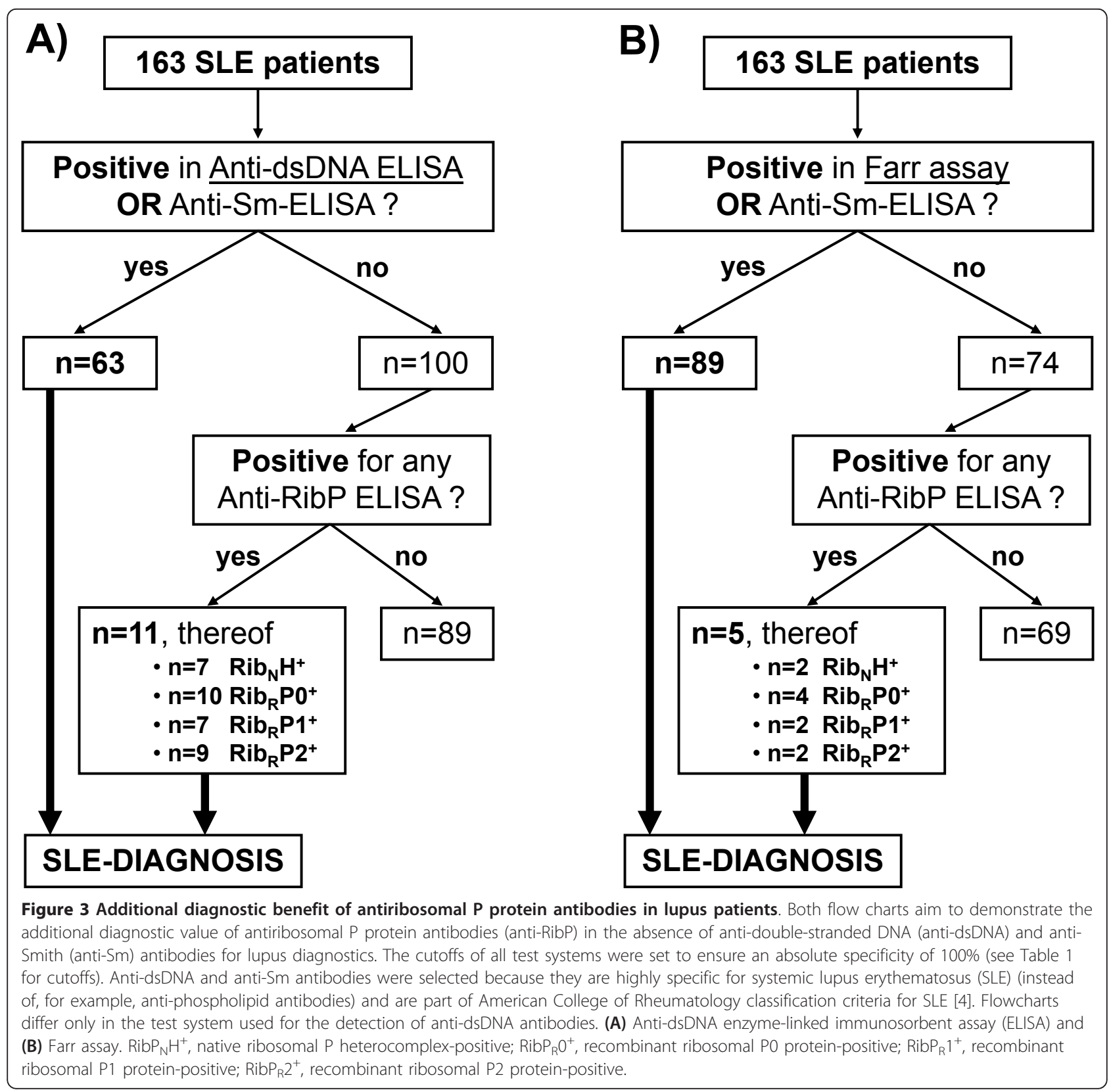


relations adjusted to 89 (54.6\%) individuals with regular diagnosis and five $(3.1 \%)$ individuals with additional diagnosis only by the presence of aRibP.

\section{Comparison of disease features in $\mathrm{aRibP}^{+}$vs. aRibP ${ }^{-}$SLE patients}

To determine the special characteristics of lupus patients with elevated aRibPs, we compared medical records, including ACR criteria, SLEDAI 2000 items and laboratory parameters, including autoantibodies, immunosuppressants and antimalarials, with those of aRibP ${ }^{-}$ lupus patients. All clinical laboratory results and detailed demographic information about the study cohort are shown in Table 2.

$\mathrm{ARibP}_{\mathrm{N}} \mathrm{H}^{+}$patients fulfilled significantly more ACR criteria and more often had photosensitivity. Moreover, the frequency of patients with decreased C3 levels was higher among aRibP ${ }_{\mathrm{N}} \mathrm{H}^{+}$patients. Lymphocytopenia was associated with the presence of aRibP $P_{R} 0$, and a higher $\gamma$-glutamyl transpeptidase (GGT) level was found in aRibP $_{\mathrm{R}} 1^{+}$patients. Anti-Sm, anti-dsDNA and anti- $\mathrm{U}_{1^{-}}$ ribonucleoprotein (anti- $\mathrm{U}_{1}-\mathrm{RNP}$ ) antibodies were much more frequent in all aRibP ${ }^{+}$patients.

\section{Comparison of disease damage in $\mathrm{aRibP}^{+}$vs. aRibP ${ }^{-}$SLE patients}

To study the prognostic role of ribosomal $\mathrm{P}$ protein antibodies, SLICC scores and WDS were assessed in aRibP ${ }^{+}$patients and in an age-, sex- and nephritismatched group of aRibP ${ }^{-}$patients at the time of blood sampling and 3 years later. Changes in damage scores ( $\triangle$ SLICC, $\triangle \mathrm{WDS}$ ) were calculated, and both groups were separately compared. Damage scores from 41 of all 58 aRibP $^{+}$patients were completely assessable at the time of blood sampling and 3 years later. There were 22 $\operatorname{aRibP}_{\mathrm{N}} \mathrm{H}^{+}, 27 \mathrm{aRibP}_{\mathrm{R}} 0^{+}, 18 \mathrm{aRibP}_{\mathrm{R}} 1^{+}$and $23 \mathrm{aRibP}_{\mathrm{R}} 2^{+}$ patients. SLICC and WDS correlated significantly with disease duration and the ages of patients, but not with ACR scores or with anti-dsDNA, anti-Sm or any antiribosomal P protein antibodies. Total disease damage and damage to every organ system separately was not significantly higher in aRibP ${ }^{+}$patients than in their aRibP ${ }^{-}$ counterparts within these 3 years. Thus, we found no prognostic role for aRibP.

\section{Discussion}

In this study, the diagnostic potential, clinical laboratory associations and correlations with disease damage of antibodies directed against the native ribosomal heterocomplex and its recombinantly produced constituents $\mathrm{P} 0, \mathrm{P} 1$ and $\mathrm{P} 2$ were investigated. $\mathrm{ARibP}_{\mathrm{R}} 0$ revealed the best diagnostic performance among all aRibP types and offered the most diagnostic benefit among sera negative for anti-dsDNA and anti-Sm antibodies. Furthermore,
$\mathrm{aRibP}_{\mathrm{R}} 0^{+}$lupus patients had significantly lower lymphocyte counts than their aRibP $\mathrm{R}_{\mathrm{R}} 0^{-}$counterparts. Finally, no prognostic relevance was found for any of the aRibPs during a 3-year period.

Our results concerning the prevalence and high specificity of aRibPs for SLE agree with data described before $[3,42]$. We further found sensitivities of $\mathrm{P}_{\mathrm{R}} \mathrm{O}>\mathrm{P}_{\mathrm{N}} \mathrm{H}>$ $\mathrm{P}_{\mathrm{R}} 2>\mathrm{P}_{\mathrm{R}} 1$ at specificities of $98 \%$ to $99 \%$ and $\mathrm{P}_{\mathrm{N}} \mathrm{H}>\mathrm{P}_{\mathrm{R}} 0$ $=\mathrm{P}_{\mathrm{R}} 2>\mathrm{P}_{\mathrm{R}} 1$ at a specificity of $100 \%$ in a cohort of 163 lupus patients. This is in contrast to another study where sensitivities of $\mathrm{P}_{R} 2=\mathrm{P}_{\mathrm{R}} 1=\mathrm{P}_{\mathrm{R}} 0$ were determined at a specificity of $100 \%$ in a cohort of 50 SLE patients [13]. Different detection systems and patient cohorts might have contributed to these divergent observations. Since all three subunits of aRibPs share the carboxylterminal epitope, it is of interest to note that an ELISA (referred as anti-C22 ELISA) detecting antibodies against this shared epitope reached the same sensitivity of $22 \%$ at a specificity of nearly $99 \%$ as aRib $P_{R} 0$ in our Berlin patient cohort [43].

We have additionally demonstrated that negativity of $\mathrm{aRibP}_{\mathrm{N}} \mathrm{H}$ does not automatically imply negativity of antibodies against its subunits, especially those against ribosomal P0. This could be due to immunologically relevant epitopes that are freely accessible using $\operatorname{RibP}_{R} 0$ alone, but not within the spatial conformation of the native heterocomplex. A biological reason for the higher frequency of $\mathrm{aRibP}_{\mathrm{R}} 0$ might be the disposability of ribosomal P0-like protein in the cell membranes of many cells, which could contribute to an increased immunogenicity [8-11].

Among the vast quantity of antibodies that are detectable in SLE, antibodies against dsDNA and Sm are highly specific and therefore most useful for the verification of the diagnosis. However, aRibPs are also discussed as a diagnostic criterion. Therefore, we asked whether aRibPs provide additional diagnostic benefit in direct comparison to anti-dsDNA and anti-Sm antibodies. Exactly $10 \%$ of sera negative in the anti-Sm and antidsDNA ELISAs were positive for aRibP $\mathrm{R}_{\mathrm{R}} \mathrm{O}$ at a specificity of $100 \%$. Even the comparison including the Farr assay revealed that $5.4 \%$ of all anti-Sm ELISA and antidsDNA RIA (Farr assay) negative sera were positive for $\mathrm{aRibP}_{\mathrm{R}} 0$ at $100 \%$ specificity. Thus, laboratories using less sensitive assays seem to benefit more from testing for aRibP in suspected cases of SLE. However, to be sure, all patients with suspected diagnosis of SLE should be tested for aRibP. Finally, we conclude that the determination of antibodies against ribosomal $\mathrm{P}$ proteins, especially those against P0, would improve the classification and diagnosis of SLE.

By comparing disease features of lupus patients with elevated aRibPs to their seronegative counterparts, we could not confirm an association of aRibP positivity 
Table 2 Comparison of the frequency: demographical and clinical data in aRibP-positive and negative SLE patients ${ }^{\mathrm{a}}$

\begin{tabular}{|c|c|c|c|c|c|c|c|c|c|c|c|c|c|}
\hline \multirow[b]{2}{*}{ Clinical data } & \multirow[b]{2}{*}{$\begin{array}{l}\text { All patients } \\
(n=163)\end{array}$} & \multicolumn{3}{|c|}{ aRibP $\mathrm{N}_{\mathrm{N}} \mathrm{H}$} & \multicolumn{3}{|c|}{$\operatorname{aRibP}_{\mathrm{R}} 0$} & \multicolumn{3}{|c|}{$\operatorname{aRibP}_{\mathrm{R}} 1$} & \multicolumn{3}{|c|}{$\operatorname{aRibP}_{\mathrm{R}} 2$} \\
\hline & & $\begin{array}{l}\text { Positive } \\
(n=30)\end{array}$ & $\begin{array}{l}\text { Negative } \\
(n=133)\end{array}$ & $P$ value & $\begin{array}{l}\text { Positive } \\
(n=34)\end{array}$ & $\begin{array}{l}\text { Negative } \\
(n=129)\end{array}$ & $P$ value & $\begin{array}{l}\text { Positive } \\
(n=24)\end{array}$ & $\begin{array}{l}\text { Negative } \\
(n=139)\end{array}$ & $P$ value & $\begin{array}{l}\text { Positive } \\
(n=28) \\
\end{array}$ & $\begin{array}{l}\text { Negative } \\
(n=135)\end{array}$ & $P$ value \\
\hline \multicolumn{14}{|l|}{ Demographics } \\
\hline Age in years, ${ }^{b}$ median & 37.0 & 36.5 & 37.0 & 0.317 & 35.0 & 37.0 & 0.081 & 35.0 & 37.0 & 0.326 & 37.0 & 37.0 & 0.467 \\
\hline Age at onset, ${ }^{c}<18$ years, $\%$ & 19.7 & 15.6 & 13.9 & 1.000 & 24.3 & 16.8 & 0.338 & 22.2 & 17.7 & 0.592 & 26.7 & 16.7 & 0.203 \\
\hline Females, ${ }^{c} \%$ & 89.8 & 84.4 & 91.2 & 0.324 & 89.2 & 90 & 1.000 & 96.3 & 88.7 & 0.314 & 90 & 89.9 & 1.000 \\
\hline SLE duration in months, ${ }^{\text {b }}$ median & 108.0 & 97.0 & 109.0 & 0.716 & 69.0 & 109.0 & 0.118 & 62.0 & 109.0 & 0.147 & 96.0 & 107.0 & 0.756 \\
\hline ACR criteria & $n=163$ & $n=30$ & $n=133$ & & $n=34$ & $n=129$ & & $n=24$ & $n=139$ & & $n=28$ & $n=135$ & \\
\hline Number of ACR criteria, ${ }^{\mathrm{b}}$ median & 6.00 & $7.00^{d}$ & $6.00^{d}$ & $0.031^{\mathrm{d}}$ & 7.00 & 6.00 & 0.059 & 6.50 & 6.00 & 0.236 & 7.00 & 6.00 & 0.076 \\
\hline Malar rash, ${ }^{\subset} \%$ & 66.2 & 73.3 & 64.6 & 0.402 & 70.6 & 65.1 & 0.684 & 70.8 & 65.5 & 0.815 & 71.4 & 65.2 & 0.662 \\
\hline Discoid rash, ${ }^{c} \%$ & 12.3 & 16.7 & 11.3 & 0.536 & 14.7 & 11.6 & 0.571 & 16.7 & 11.5 & 0.501 & 25.0 & 9.63 & 0.0504 \\
\hline Photosensitivity, ${ }^{c} \%$ & 46.6 & $63.3^{\mathrm{d}}$ & $42.9^{d}$ & $0.046^{d}$ & 58.8 & 43.4 & 0.125 & 62.5 & 43.9 & 0.121 & 53.6 & 45.2 & 0.533 \\
\hline Oral ulcers, ${ }^{c} \%$ & 18.4 & 23.3 & 17.3 & 0.441 & 23.5 & 17.1 & 0.456 & 12.5 & 19.4 & 0.573 & 17.9 & 18.5 & 1.000 \\
\hline Arthritis, ${ }^{c} \%$ & 84.1 & 90.0 & 82.7 & 0.417 & 94.1 & 81.4 & 0.111 & 91.7 & 82.7 & 0.373 & 96.4 & 81.5 & 0,0506 \\
\hline Serositis, ${ }^{c} \%$ & 44.2 & 36.7 & 45.9 & 0.419 & 38.2 & 45.7 & 0.561 & 41.7 & 44.6 & 0.828 & 39.3 & 45.2 & 0.677 \\
\hline Renal disorder, ${ }^{c} \%$ & 42.9 & 46.7 & 42.2 & 0.686 & 44.1 & 42.6 & 1.000 & 37.5 & 43.9 & 0.658 & 39.3 & 43.7 & 0.834 \\
\hline Epilepsy or psychosis, ${ }^{c} \%$ & 12.9 & 20.0 & 11.3 & 0.228 & 14.7 & 12.4 & 0.774 & 25.0 & 10.8 & 0.091 & 21.4 & 11.1 & 0.209 \\
\hline Hematologic, ${ }^{c} \%$ & 63.8 & 70.0 & 62.4 & 0.530 & 67.6 & 62.8 & 0.690 & 58.3 & 64.7 & 0.646 & 67.9 & 62.9 & 0.672 \\
\hline Immune disorder and ANA, \% & 100 & 100 & 100 & - & 100 & 100 & - & 100 & 100 & - & 100 & 100 & - \\
\hline SLEDAI & $n=101$ & $n=17$ & $n=84$ & & $n=22$ & $n=79$ & & $n=17$ & $n=84$ & & $n=17$ & $n=84$ & \\
\hline SLEDAI, ${ }^{\mathrm{b}}$ median & 6.00 & 6.00 & 6.00 & 0.517 & 6.00 & 6.00 & 0.886 & 6.00 & 6.00 & 0.915 & 6.00 & 6.00 & 0.256 \\
\hline Vasculitis, ${ }^{c} \%$ & 7.92 & 5.89 & 8.33 & 1.000 & 4.55 & 8.86 & 0.682 & 11.8 & 7.14 & 0.621 & 5.89 & 8.33 & 1.000 \\
\hline Arthritis, ${ }^{c} \%$ & 33.7 & 23.5 & 35.7 & 0.408 & 22.7 & 36.7 & 0.309 & $11.8^{d}$ & $38.1^{d}$ & $0.048^{d}$ & $11.8^{\mathrm{d}}$ & $38.1^{d}$ & $0.048^{d}$ \\
\hline Hematuria, ${ }^{c} \%$ & 6.93 & 11.8 & 5.95 & 0.335 & 4.55 & 7.59 & 1.000 & 0.00 & 9.52 & 0.346 & 0.00 & 9.41 & 0.346 \\
\hline Proteinuria, ${ }^{c} \%$ & 9.90 & 17.6 & 8.33 & 0.366 & 9.09 & 10.1 & 1.000 & 5.88 & 10.7 & 1.000 & 5.88 & 10.7 & 1.000 \\
\hline Exanthema, ${ }^{c} \%$ & 32.7 & 11.8 & 36.9 & 0.0503 & 27.3 & 34.2 & 0.615 & 23.5 & 34.5 & 0.572 & 23.5 & 34.5 & 0.572 \\
\hline Alopecia, ${ }^{c} \%$ & 16.8 & 23.5 & 15.5 & 0.478 & 27.3 & 13.9 & 0.195 & 17.6 & 16.7 & 1.000 & 17.6 & 16.7 & 1.000 \\
\hline Pericarditis, ${ }^{c} \%$ & 6.93 & 5.88 & 7.14 & 1.000 & 9.09 & 6.33 & 0.645 & 11.8 & 5.95 & 0.335 & 5.88 & 7.14 & 1.000 \\
\hline Complement deficiency, ${ }^{c} \%$ & 57.4 & 64.7 & 55.9 & 0.597 & 68.2 & 51.2 & 0.331 & 58.8 & 57.1 & 1.000 & 64.7 & 55.9 & 0.597 \\
\hline Fever $^{c} \%$ & 3.96 & 0.00 & 4.67 & 1.000 & 4.55 & 3.79 & 1.000 & 0.00 & 4.76 & 1.000 & 0.00 & 4.76 & 1.000 \\
\hline \multicolumn{14}{|l|}{ Drugs } \\
\hline Prednisolone, ${ }^{c} \%$ & 89.9 & 93.1 & 89.2 & 0.738 & 90.9 & 89.7 & 1.000 & 86.9 & 90.4 & 0.706 & 88.9 & 90.3 & 0.734 \\
\hline Azathioprine, ${ }^{c} \%$ & 30.8 & 27.6 & 31.5 & 0.825 & 36.4 & 29.4 & 0.526 & 17.4 & 33.1 & 0.151 & 29.6 & 31.1 & 1.000 \\
\hline Cyclophosphamide, ${ }^{c} \%$ & 8.81 & 6.89 & 9.23 & 1.000 & 12.1 & 7.94 & 0.491 & 18.8 & 7.75 & 0.155 & 11.1 & 8.33 & 0.708 \\
\hline Mycophenolate mofetil, ${ }^{c} \%$ & 20.5 & 20.7 & 19.7 & 1.000 & 15.2 & 22.2 & 0.474 & 30.4 & 19.1 & 0.265 & 22.2 & 20.5 & 0.799 \\
\hline Methotrexate, ${ }^{\complement} \%$ & 3.04 & 3.23 & 3.01 & 1.000 & 8.33 & 1.56 & 0.071 & 7.69 & 2.17 & 0.179 & 3.45 & 2.96 & 1.000 \\
\hline Hydroxychloroquine sulfate, ${ }^{c} \%$ & 35.4 & 50.0 & 32.3 & 0.085 & 36.4 & 35.2 & 1.000 & 30.4 & 36.3 & 0.645 & 37.0 & 35.1 & 0.829 \\
\hline
\end{tabular}


Table 2 Comparison of the frequency: demographical and clinical data in aRibP-positive and negative SLE patients ${ }^{\mathrm{a}}$ (Continued)

\begin{tabular}{|c|c|c|c|c|c|c|c|c|c|c|c|c|c|}
\hline Leukocytes, ${ }^{\mathrm{b}}$ median & 6.50 & 7.03 & 6.40 & 0.539 & 7.00 & 6.30 & 0.136 & 6.58 & 6.40 & 0.479 & 6.50 & 6.49 & 0.933 \\
\hline Lymphocytes, ${ }^{b}$ median & 0.87 & 0.67 & 0.87 & 0.164 & $0.63^{d}$ & $0.92^{d}$ & $0.036^{d}$ & 0.91 & 0.86 & 0.957 & 0.70 & 0.93 & 0.076 \\
\hline Monocytes, median & 0.35 & 0.34 & 0.35 & 0.769 & 0.33 & 0.35 & 0.584 & 0.48 & 0.35 & 0.301 & 0.31 & 0.35 & 0.540 \\
\hline$A L T$, b,e median & 19.4 & 14.4 & 20.0 & 0.501 & 22.0 & 19.2 & 0.824 & 20.7 & 19.0 & 0.661 & 14.7 & 20.0 & 0.547 \\
\hline $\mathrm{AST}_{\text {, }}^{\mathrm{b}, \mathrm{e}}$ median & 25.0 & 28.0 & 24.9 & 0.212 & 25.5 & 25.0 & 0.953 & 27.5 & 24.9 & 0.129 & 25.0 & 25.0 & 0.568 \\
\hline $\mathrm{GGT}^{\mathrm{b}, \mathrm{e}}$ median & 23.0 & 26.0 & 21.6 & 0.278 & 24.0 & 21.1 & 0.423 & $29.0^{d}$ & $21.0^{d}$ & $0.047^{d}$ & 29.0 & 21.1 & 0.108 \\
\hline Low C3, ${ }^{c} \%$ & 47.6 & $65.5^{\mathrm{d}}$ & $43.2^{\mathrm{d}}$ & $0.038^{d}$ & 58.1 & 44.8 & 0.227 & 54.2 & 46.3 & 0.511 & 61.5 & 44.6 & 0.134 \\
\hline Low $C 4, c \%$ & 34.7 & 37.9 & 33.9 & 0.670 & 38.7 & 33.6 & 0.672 & 37.5 & 34.1 & 0.816 & 38.4 & 33.9 & 0.656 \\
\hline $\mathrm{CRP},{ }^{\mathrm{b}}$ median & 0.38 & 0.30 & 0.40 & 0.771 & 0.28 & 0.42 & 0.454 & 0.25 & 0.42 & 0.379 & 26.0 & 25.9 & 0.803 \\
\hline $\mathrm{ESR}^{\mathrm{b}}$ median & 24.0 & 25.0 & 24.0 & 0.616 & 22.0 & 25.0 & 0.740 & 21.5 & 25.0 & 0.572 & 23.0 & 24.5 & 0.819 \\
\hline \multicolumn{14}{|l|}{ Autoantibodies } \\
\hline High anti-Sm, ${ }^{c} \%$ & 33.7 & $63.3^{d}$ & $27.1^{\mathrm{d}}$ & $4 \times 10^{-3 d}$ & $70.6^{d}$ & $24.2^{d}$ & $<10^{-4 d}$ & $66.7^{d}$ & $28.1^{d}$ & $7 \times 10^{-3 d}$ & $60.7^{d}$ & $28.1^{d}$ & $0.002^{d}$ \\
\hline Increased anti- dsDNA in ELISA, c \% & 42.3 & $70.0^{\mathrm{d}}$ & $36.8^{\mathrm{d}}$ & $0.002^{d}$ & $67.8^{\mathrm{d}}$ & $36.4^{d}$ & $0.002^{\mathrm{d}}$ & $75.0^{d}$ & $37.4^{\mathrm{d}}$ & $7 \times 10^{-3 d}$ & $60.7^{d}$ & $39.3^{d}$ & $0.058^{d}$ \\
\hline Increased anti- dsDNA in RIA, ${ }^{c} \%$ & 56.4 & $76.7^{d}$ & $51.9^{\mathrm{d}}$ & $0.015^{d}$ & $79.4^{d}$ & $50.4^{d}$ & $0.003^{d}$ & $83.3^{d}$ & $51.8^{d}$ & $0.004^{d}$ & $78.6^{d}$ & $51.9^{d}$ & $0.012^{d}$ \\
\hline Increased anti- $U_{1}$-RNP in anamnesis, ${ }^{c} \%$ & 28.9 & $59.1^{d}$ & $21.7^{\mathrm{d}}$ & $0.001^{d}$ & $50.0^{d}$ & $23.3^{d}$ & $0.021^{d}$ & $62.5^{\mathrm{d}}$ & $23.5^{\mathrm{d}}$ & $0.003^{d}$ & $54.5^{\mathrm{d}}$ & $22.7^{d}$ & $0.007^{d}$ \\
\hline Increased anti- nucleosomes, ${ }^{c} \%$ & 50.9 & 60.0 & 48.9 & 0.315 & 64.7 & 47.3 & 0.084 & 62.5 & 48.9 & 0.271 & $70.4^{\mathrm{d}}$ & $47.1^{d}$ & $0.035^{\mathrm{d}}$ \\
\hline Increased anti- Ro/SS-A, ${ }^{c} \%$ & 40.5 & 50.0 & 38.3 & 0.304 & 41.2 & 40.3 & 1.000 & 37.5 & 41.0 & 0.824 & 39.3 & 40.7 & 1.000 \\
\hline Increased anti- La/SS-B, ${ }^{C} \%$ & 12.3 & 20.0 & 10.5 & 0.213 & 8.82 & 13.2 & 0.769 & $0.00^{d}$ & $14.4^{\mathrm{d}}$ & $0.046^{\mathrm{d}}$ & 3.57 & 14.1 & 0.203 \\
\hline
\end{tabular}

${ }^{a}$ SLE, systemic lupus erythematosus; ACR, American College of Rheumatology; ANA, antinuclear antibody; SLEDAl, Systemic Lupus Erythematosus Disease Activity Index; ALT, alanine aminotransferase; AST, aspartate aminotransferase; GGT, $\gamma$-glutamyl transpeptidase; CRP, C-reactive protein; ESR, erythrocyte sedimentation rate; ELISA, enzyme-linked immunosorbent assay; RIA, radioimmunoassay; anti-Sm, anti-Smith antibody; antidsDNA, anti-double-stranded DNA antibody; Ro/SS-A, anti- Sjögren's syndrome antigen A; La/SS-B, anti- Sjögren's syndrome antigen B; U1-RNP, U $U_{1}$-ribonucleoprotein; aRibP, anti-ribosomal P protein antibody; ${ }_{a R i b P} \mathrm{H}$, antibodies against native ribosomal $\mathrm{P}$ heterocomplex; aRibP $\mathrm{R}_{\mathrm{R}}$, antibodies against recombinant ribosomal P0 protein; aRibP $\mathrm{P}_{\mathrm{R}} 1$, antibodies against recombinant ribosomal $\mathrm{P} 1$ protein; aRibP $\mathrm{R}_{\mathrm{R}} 2$, antibodies

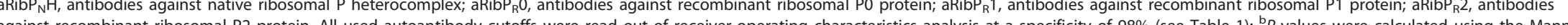
Whitney $U$ test; ${ }^{c} P$ values were calculated using Fisher's exact test; ${ }^{d}$ statistically significant findings, highlighted in bold; ${ }^{e} G G T$ values of men and from other laboratories have been standardized on cutoffs of GGT for women at the Charité University Hospital. 
with lupus nephritis, short disease duration, high disease activity or juvenile onset. These results might be influenced by the Caucasian ethnicity of the study cohort and differences of the test systems. Cases of neuropsychiatric lupus $[28,29]$ and subtypes of lupus nephritis were not recorded in our study.

The most striking association of aRibPs with disease features was that aRibP $\mathrm{R}_{\mathrm{R}} 0^{+}$lupus patients had significantly lower lymphocytes than $\mathrm{aRibP}_{\mathrm{R}} 0^{-}$lupus patients. Interestingly, a P0-like protein is also detectable in the plasma membranes of different cells, including lymphocytes [11]. Further, the aRibPs are able to bind and penetrate $\mathrm{T}$-cell lines $[44,45]$, and especially $\operatorname{aRibP}_{\mathrm{R}} 0$ can induce apoptosis in Jurkat T-cells [46]. In that context, our data confirm the thesis of Sun et al. [46] that $\operatorname{aRibP}_{\mathrm{R}} 0$ contributes in a clinically relevant manner to lymphocytopenia in SLE. Thus, clinicians should keep $\operatorname{aRibP}_{\mathrm{R}} 0$ in mind as one differential diagnosis for lymphocytopenia in SLE, along with viral status, drug side effects, hematologic malignancies and other factors.

Another remarkable, significant clinical laboratory association was that $\mathrm{aRibP}_{\mathrm{R}} 1^{+}$patients had an elevated GGT value. The participation of aRibPs in liver pathology of SLE was previously reported in cell cultures $[9,11,46]$ and in case reports [19-21]. However, $\mathrm{aRibP}_{\mathrm{R}} 0$ were most frequently in focus because of their membrane-bound isoform [8-11]. As such, in a study of 61 Japanese patients [22], no significant association was found between $\mathrm{aRibP}_{\mathrm{R}} 0$ and liver enzymes alanine aminotransferase or aspartate aminotransferase, but the GGT level was not assessed. The correlation shown here between GGT and $\mathrm{aRibP}_{\mathrm{R}} 1$ indicates a possible association of aRibP with lupus hepatitis. However, we do not have a clear definition of lupus hepatitis, and it is hard to rule out other causes, such as nutrition, drugs and other autoimmune hepatitis forms. Longitudinal analysis of aRibPs with liver function tests, including GGT in parallel, might reveal this association best.

Up to now, accepted prognostic factors in SLE have only been lupus nephritis and neuropsychiatric SLE. No prognostic laboratory parameter is known. In this study, we investigated whether aRibP ${ }^{+}$lupus patients would develop more or specific disease damage measured by SLICC or WDS after 3 years than their aRibP- counterparts. However, no significant correlations with any of the antiribosomal $\mathrm{P}$ protein antibodies could be found over a 3-year period. Conclusively, we first show that aRibPs are not a prognostic parameter for damage in SLE. Further study with more patients and over longer observation time frames could strengthen this result.

\section{Conclusions}

In summary, antiribosomal $\mathrm{P}$ protein antibodies are very specific for SLE, can also be found in patients with negative anti-dsDNA and anti-Sm antibodies and therefore have to be discussed in the upcoming classification and diagnostic criteria for SLE. Among all four investigated aRibPs, aRibP ${ }_{R} 0$ was the most abundant and should be used for the diagnosis of SLE. High aRibP ${ }_{R} 0$ titers can be associated with lymphocytopenia, and high $\mathrm{aRibP}_{\mathrm{R}} 1$ titers can be associated with an elevated GGT level. A prognostic role of antiribosomal $P$ protein antibodies is unlikely.

\section{Abbreviations}

$\operatorname{aRibP}_{N} \mathrm{H}$ : antibodies against native ribosomal $\mathrm{P}$ heterocomplex; $\mathrm{aRibP}_{\mathrm{R}} \mathrm{O}$ antibodies against recombinant ribosomal $\mathrm{P} 0$ protein; $\mathrm{ARibP}_{\mathrm{R}} 1$ : antibodies against recombinant ribosomal $\mathrm{P} 1$ protein; $\operatorname{RRibP}_{\mathrm{R}} 2$ : antibodies against recombinant ribosomal P2 protein; aRibPs: anti-ribosomal P protein antibodies

\section{Acknowledgements}

This work was supported by grants from EUROIMMUN AG and the German Research Foundation (Collaborative Research Centre SFB650, TP17).

\section{Author details}

'Department of Rheumatology and Clinical Immunology, Charité Universitätsmedizin Berlin, Chariteplatz 1, Berlin D-10117, Germany. 2EUROIMMUN Medizinische Labordiagnostika AG, Seekamp 31, Lübeck D23560, Germany.

\section{Authors' contributions}

RB had full access to all of the data in the study and takes responsibility for the integrity of the data and the accuracy of the data analysis. RB, CD, FH and WSchlumberger contributed to study design. FB, RB, US, KE and AR contributed to the acquisition of data. $\mathrm{FB}, \mathrm{RB}$ and $\mathrm{FH}$ contributed to analysis and interpretation of data. RB, GRB, WSchlumberger, $C D$ and $F H$ contributed to manuscript preparation. FB and RB contributed to statistical analysis. KE, CD, WStöcker, $\mathrm{FH}$ and WSchlumberger contributed to overall project management.

\section{Competing interests}

RB was employed from August 2006 until March 2009 in the Charité Universitätsmedizin Berlin, Berlin, Germany under third-party funds paid by EUROIMMUNE AG. CD and AR are employees of EUROIMMUN AG, Lübeck, Germany. WSchlumberger and WStöcker are board members of

EUROIMMUN AG. The other authors have declared no conflict of interest.

Received: 21 August 2010 Revised: 6 January 2011

Accepted: 10 February 2011 Published: 10 February 2011

\section{References}

1. Rahman A, Isenberg DA: Systemic lupus erythematosus. N Engl J Med 2008, 358:929-939.

2. Riemekasten G, Hahn BH: Key autoantigens in SLE. Rheumatology (Oxford) 2005, 44:975-982.

3. Kiss $E$, Shoenfeld $Y$ : Are anti-ribosomal $P$ protein antibodies relevant in systemic lupus erythematosus? Clin Rev Allergy Immunol 2007, 32:37-46.

4. Hochberg MC: Updating the American College of Rheumatology revised criteria for the classification of systemic lupus erythematosus. Arthritis Rheum 1997, 40:1725.

5. Tan EM, Cohen AS, Fries JF, Masi AT, McShane DJ, Rothfield NF, Schaller JG, Talal N, Winchester RJ: The 1982 revised criteria for the classification of systemic lupus erythematosus. Arthritis Rheum 1982, 25:1271-1277.

6. Elkon K, Skelly S, Parnassa A, Moller W, Danho W, Weissbach H, Brot N: Identification and chemical synthesis of a ribosomal protein antigenic 
determinant in systemic lupus erythematosus. Proc Natl Acad Sci USA 1986, 83:7419-7423.

7. Francoeur AM, Peebles $\mathrm{CL}$, Heckman KJ, Lee JC, Tan EM: Identification of ribosomal protein autoantigens. J Immunol 1985, 135:2378-2384.

8. Yoshio T, Masuyama J, Kano S: Antiribosomal Po protein antibodies react with the surface of human umbilical vein endothelial cells. J Rheumatol 1996, 23:1311-1312.

9. Koscec M, Koren E, Wolfson-Reichlin M, Fugate RD, Trieu E, Targoff IN, Reichlin M: Autoantibodies to ribosomal P proteins penetrate into live hepatocytes and cause cellular dysfunction in culture. J Immunol 1997, 159:2033-2041.

10. Reichlin M: Presence of ribosomal P protein on the surface of human umbilical vein endothelial cells. J Rheumatol 1996, 23:1123-1125.

11. Koren E, Reichlin MW, Koscec M, Fugate RD, Reichlin M: Autoantibodies to the ribosomal $\mathrm{P}$ proteins react with a plasma membrane-related target on human cells. J Clin Invest 1992, 89:1236-1241.

12. Mahler M, Kessenbrock K, Szmyrka M, Takasaki Y, Garcia-De La Torre I, Shoenfeld Y, Hiepe F, Shun-le C, von Muhlen CA, Locht H, Hopfl P, Wiik A, Reeves W, Fritzler MJ: International multicenter evaluation of autoantibodies to ribosomal P proteins. Clin Vaccine Immunol 2006, 13:77-83.

13. Mahler M, Kessenbrock K, Raats J, Fritzler MJ: Technical and clinical evaluation of anti-ribosomal P protein immunoassays. J Clin Lab Anal 2004, 18:215-223.

14. Ghirardello A, Caponi L, Franceschini F, Zampieri S, Quinzanini M, Bendo R, Bombardieri S, Gambari PF, Doria A: Diagnostic tests for antiribosomal $p$ protein antibodies: a comparative evaluation of immunoblotting and ELISA assays. J Autoimmun 2002, 19:71-77.

15. Massardo L, Burgos P, Martinez ME, Perez R, Calvo M, Barros J, Gonzalez A, Jacobelli S: Antiribosomal P protein antibodies in Chilean SLE patients: no association with renal disease. Lupus 2002, 11:379-383.

16. Gerli R, Caponi L, Tincani A, Scorza R, Sabbadini MG, Danieli MG, De Angelis V, Cesarotti M, Piccirilli M, Quartesan R, Moretti P, Cantoni C, Franceschini F, Cavazzana I, Origgi L, Vanoli M, Bozzolo E, Ferrario L, Padovani A, Gambini O, Vanzulli L, Croce D, Bombardieri S: Clinical and serological associations of ribosomal $\mathrm{P}$ autoantibodies in systemic lupus erythematosus: prospective evaluation in a large cohort of Italian patients. Rheumatology (Oxford) 2002, 41:1357-1366.

17. Briani C, Lucchetta M, Ghirardello A, Toffanin E, Zampieri S, Ruggero $S$, Scarlato M, Quattrini A, Bassi N, Ermani M, Battistin L, Doria A: Neurolupus is associated with anti-ribosomal P protein antibodies: an inception cohort study. J Autoimmun 2009, 32:79-84.

18. Takeda I, Iwadate H, Sugisaki K, Takahashi A, Nogae S, Kanno T, Kasukawa R: Anti-ribosomal $\mathrm{P}$ antibodies are associated with nephritis, vascular thrombosis and lymphocytopenia in patients with systemic lupus erythematosus. Fukushima J Med Sci 2005, 51:11-18.

19. Arnett FC, Reichlin M: Lupus hepatitis: an under-recognized disease feature associated with autoantibodies to ribosomal P. Am J Med 1995, 99:465-472.

20. Kaw R, Gota C, Bennett A, Barnes D, Calabrese L: Lupus-related hepatitis: complication of lupus or autoimmune association? Case report and review of the literature. Dig Dis Sci 2006, 51:813-818.

21. Koren E, Schnitz W, Reichlin M: Concomitant development of chronic active hepatitis and antibodies to ribosomal P proteins in a patient with systemic lupus erythematosus. Arthritis Rheum 1993, 36:1325-1328.

22. Ohira H, Takiguchi J, Rai T, Abe K, Yokokawa J, Sato Y, Takeda I, Kanno T: High frequency of anti-ribosomal P antibody in patients with systemic lupus erythematosus-associated hepatitis. Hepatol Res 2004, 28:137-139.

23. Hulsey M, Goldstein R, Scully L, Surbeck W, Reichlin M: Anti-ribosomal P antibodies in systemic lupus erythematosus: a case-control study correlating hepatic and renal disease. Clin Immunol Immunopathol 1995, 74:252-256.

24. Reichlin M, Broyles TF, Hubscher O, James J, Lehman TA, Palermo R, Stafford HA, Taylor-Albert E, Wolfson-Reichlin M: Prevalence of autoantibodies to ribosomal P proteins in juvenile-onset systemic lupus erythematosus compared with the adult disease. Arthritis Rheum 1999, 42:69-75.

25. Hoffman IE, Lauwerys BR, De Keyser F, Huizinga TW, Isenberg D, Cebecauer L, Dehoorne J, Joos R, Hendrickx G, Houssiau F, Elewaut D: Juvenile-onset systemic lupus erythematosus: different clinical and serological pattern than adult-onset systemic lupus erythematosus. Ann Rheum Dis 2009, 68:412-415.

26. Haddouk S, Marzouk S, Jallouli M, Fourati H, Frigui M, Hmida YB, Koubaa F. Sellami W, Baklouti S, Hachicha J, Bahloul Z, Masmoudi H: Clinical and diagnostic value of ribosomal $\mathrm{P}$ autoantibodies in systemic lupus erythematosus. Rheumatology (Oxford) 2009.

27. do Nascimento AP, Viana Vdos S, Testagrossa Lde A, Leon EP, Borba EF, Barros RT, Bonfá E: Antibodies to ribosomal P proteins: a potential serologic marker for lupus membranous glomerulonephritis. Arthritis Rheum 2006, 54:1568-1572.

28. Karassa FB, Afeltra A, Ambrozic A, Chang DM, De Keyser F, Doria A, Galeazzi M, Hirohata S, Hoffman IE, Inanc M, Massardo L, Mathieu A, Mok CC, Morozzi G, Sanna G, Spindler AJ, Tzioufas AG, Yoshio T, loannidis JP: Accuracy of anti-ribosomal P protein antibody testing for the diagnosis of neuropsychiatric systemic lupus erythematosus: an international meta-analysis. Arthritis Rheum 2006, 54:312-324.

29. Hanly JG, Urowitz MB, Siannis F, Farewell V, Gordon C, Bae SC, Isenberg D, Dooley MA, Clarke A, Bernatsky S, Gladman D, Fortin PR, Manzi S, Steinsson K, Bruce IN, Ginzler E, Aranow C, Wallace DJ, Ramsey-Goldman R, van Vollenhoven R, Sturfelt G, Nived O, Sanchez-Guerrero J, Alarcon GS, Petri M, Khamashta M, Zoma A, Font J, Kalunian K, Douglas J, et al: Autoantibodies and neuropsychiatric events at the time of systemic lupus erythematosus diagnosis: results from an international inception cohort study. Arthritis Rheum 2008, 58:843-853.

30. Bertolaccini ML, Murru V, Alba P, Khamashta MA: Lack of association of antibodies to ribosomal $\mathrm{P}$ proteins with lupus membranous glomerulonephritis: comment on the article by Do Nascimento et al. Arthritis Rheum 2006, 54:4025-4026, author reply 4026-4027.

31. Teh LS, Hay EM, Amos N, Black D, Huddy A, Creed F, Bernstein RM, Holt PJ, Williams BD: Anti-P antibodies are associated with psychiatric and focal cerebral disorders in patients with systemic lupus erythematosus. $\mathrm{Br} J$ Rheumatol 1993, 32:287-290.

32. Tzioufas AG, Tzortzakis NG, Panou-Pomonis E, Boki KA, SakarellosDaitsiotis M, Sakarellos C, Moutsopoulos HM: The clinical relevance of antibodies to ribosomal-P common epitope in two targeted systemic lupus erythematosus populations: a large cohort of consecutive patients and patients with active central nervous system disease. Ann Rheum Dis 2000, 59:99-104.

33. Subcommittee for scleroderma criteria of the American Rheumatism Association Diagnostic and Therapeutic Criteria Committee: Preliminary criteria for the classification of systemic sclerosis (scleroderma). Arthritis Rheum 1980, 23:581-590.

34. Vitali C, Bombardieri S, Jonsson R, Moutsopoulos HM, Alexander EL, Carsons SE, Daniels TE, Fox PC, Fox RI, Kassan SS, Pillemer SR, Talal N, Weisman MH: Classification criteria for Sjögren's syndrome: a revised version of the European criteria proposed by the American-European Consensus Group. Ann Rheum Dis 2002, 61:554-558.

35. Arnett FC, Edworthy SM, Bloch DA, McShane DJ, Fries JF, Cooper NS, Healey LA, Kaplan SR, Liang MH, Luthra HS, Medsger TA Jr, Mitchell DM, Neustadt DH, Pinals RS, Schaller JG, Sharp JT, Wilder RL, Hunder GG: The American Rheumatism Association 1987 revised criteria for the classification of rheumatoid arthritis. Arthritis Rheum 1988, 31:315-324.

36. Gladman DD, Ibanez D, Urowitz MB: Systemic lupus erythematosus disease activity index 2000. J Rheumatol 2002, 29:288-291.

37. Griffiths B, Mosca M, Gordon C: Assessment of patients with systemic lupus erythematosus and the use of lupus disease activity indices. Best Pract Res Clin Rheumatol 2005, 19:685-708.

38. Cook RJ, Gladman DD, Pericak D, Urowitz MB: Prediction of short term mortality in systemic lupus erythematosus with time dependent measures of disease activity. J Rheumatol 2000, 27:1892-1895.

39. Ruperto N, Bazso A, Ravelli A, Malattia C, Filocamo G, Pistorio A, Rodriguez Lozano AL, Viola S, Martini A: The Paediatric Rheumatology International Trials Organization (PRINTO). Lupus 2007, 16:670-676.

40. Stoll T, Seifert B, Isenberg DA: SLICC/ACR Damage Index is valid, and renal and pulmonary organ scores are predictors of severe outcome in patients with systemic lupus erythematosus. Br J Rheumatol 1996, 35:248-254.

41. Gladman D, Ginzler E, Goldsmith C, Fortin P, Liang M, Urowitz M, Bacon P, Bombardieri S, Hanly J, Hay E, Isenberg D, Jones J, Nived O, Petri M, Richter M, Sanchez-Guerrero J, Snaith M, Sturfelt G, Simmons D: Systemic 
Lupus International Collaborative Clinics: development of a damage index in systemic lupus erythematosus. J Rheumatol 1992, 19:1820-1821.

42. Ersvaer E, Bertelsen LT, Espenes LC, Bredholt T, Boe SO, Iversen BM, Bruserud O, Ulvestad E, Gjertsen BT: Characterization of ribosomal P autoantibodies in relation to cell destruction and autoimmune disease. Scand I Immunol 2004, 60:189-198.

43. Mahler M, Agmon-Levin N, van Liempt M, Shoenfeld Y, Waka A, Hiepe F, Swart A, Gürtler I, Fritzler MJ: Multi-center evaluation of autoantibodies to the major ribosomal P C22 epitope. Rheumatol Int

44. Stafford HA, Chen AE, Anderson CJ, Paul AG, Wyatt EL, Lee LA, Neas BR: Anti-ribosomal and 'P-peptide'-specific autoantibodies bind to $T$ lymphocytes. Clin Exp Immunol 1997, 109:12-19.

45. Reichlin M: Cellular dysfunction induced by penetration of autoantibodies into living cells: cellular damage and dysfunction mediated by antibodies to dsDNA and ribosomal P proteins. J Autoimmun 1998, 11:557-561.

46. Sun KH, Tang SJ, Lin ML, Wang YS, Sun GH, Liu WT: Monoclonal antibodies against human ribosomal P proteins penetrate into living cells and cause apoptosis of Jurkat T cells in culture. Rheumatology (Oxford) 2001 40:750-756.

doi:10.1186/ar3244

Cite this article as: Barkhudarova et al.: Diagnostic value and clinical

laboratory associations of antibodies against recombinant ribosomal P0,

$\mathrm{P} 1$ and $\mathrm{P} 2$ proteins and their native heterocomplex in a Caucasian cohort with systemic lupus erythematosus. Arthritis Research \& Therapy 2011 13:R20.

\section{Submit your next manuscript to BioMed Central and take full advantage of:}

- Convenient online submission

- Thorough peer review

- No space constraints or color figure charges

- Immediate publication on acceptance

- Inclusion in PubMed, CAS, Scopus and Google Scholar

- Research which is freely available for redistribution

Submit your manuscript at www.biomedcentral.com/submit 